\title{
Managing Genetic Hemochromatosis: An Overview of Dietary Measures, Which May Reduce Intestinal Iron Absorption in Persons With Iron Overload
}

\author{
Nils Thorm Milman
}

\begin{abstract}
Genetic hemochromatosis causes iron overload by excess absorption of dietary iron, due to a decreased expression of hepcidin. The objective was to elaborate dietary recommendations that can reduce intestinal iron absorption in hemochromatosis patients, based on our present knowledge of the iron contained in nutrients and the mechanisms of iron uptake. This is a narrative review. Literature search in PubMed and Google Scholar of papers dealing with iron absorption from the diet was conducted. Most important proposed dietary recommendations are: 1) Choose a varied vegetarian, semi-vegetarian or flexitarian diet. A "veggie-lacto-ovo-poultry-pescetarian" diet seems optimal. Avoid iron enriched foods and iron supplements. 2) Eat many vegetables and fruits, at least $600 \mathrm{~g}$ per day. Choose protein rich pulses and legumes (e.g., kidney- and soya beans). Fresh fruits should be eaten between meals. 3) Abstain from red meat from mammals and choose the lean, white meat from poultry. Avoid processed meat, offal and blood containing foods. Eat no more than $200 \mathrm{~g}$ meat from poultry per week. Choose fish, eggs, vegetables and protein rich legumes the other days. Eat fish two to four times a week as main course, $350-500 \mathrm{~g}$ fish per week, of which half should be fat fish. 4) Choose whole grain products in cereals and bread. Avoid iron enriched grains. Choose nonsourdough, yeast-fermented bread with at least 50\% whole grain. 5) Choose vegetable oils, and low-fat dairy products. 6) Eat less sugar and salt. Choose whole foods and foods with minimal processing and none or little added sugar or salt. 7) Quench your thirst in water. Drink green- or black tea, coffee, or low-fat milk with the meals, alternatively water or non-alcoholic beer. Fruit juices must be consumed between meals. Abstain from alcoholic beverages. Drink soft drinks, non-alcoholic beer, or non-alcoholic wine instead. These advices are close to the official Danish dietary recommendations in 2021. In the management of hemochromatosis, dietary modifications that lower iron intake and decrease iron bioavailability may provide additional measures to reduce iron uptake from the foods and reduce the number of phlebotomies. However, there is a need for large, prospective, randomized studies that specifically evaluate the effect of dietary interventions.
\end{abstract}

Manuscript submitted January 29, 2021, accepted February 23, 2021

Published online April 21, 2021

Department of Clinical Biochemistry, Naestved Hospital, University College Zealand, DK-4700 Naestved, Denmark. Email: nils.milman@outlook.com

doi: https://doi.org/10.14740/gr1366
Keywords: Diet therapy; Genetic hemochromatosis; Iron absorption; Iron overload

\section{Introduction}

The most prevalent variants of genetic hemochromatosis in populations of northwestern European ancestry are caused by mutations (C282Y, H63D, S65C) in the HFE-gene located on chromosome 6, and designated $H F E$-hemochromatosis [1, 2]. $\mathrm{C} 282 \mathrm{Y}$ and $\mathrm{H} 63 \mathrm{D}$ are the most common mutations and homozygosity for $\mathrm{C} 282 \mathrm{Y}(\mathrm{C} 282 \mathrm{Y} / \mathrm{C} 282 \mathrm{Y})$ is the predominant cause for the disorder in $93-95 \%$ of all the diagnosed cases [1-4]. The frequency of $\mathrm{C} 282 \mathrm{Y} / \mathrm{C} 282 \mathrm{Y}$ homozygosity in the population ranges from $0.4 \%$ in Denmark $[3,4]$ to $0.6 \%$ in England [5] and $0.8 \%$ in Ireland [6].

Genetic hemochromatosis is characterized by an increased and excessive intestinal dietary iron uptake, of both nonheme and heme iron [1,7-9], which over the years can lead to accumulation of excess iron in the body and various organs causing clinical symptoms of iron overload. For an overview of the disorder/disease, see references $[1,10]$. Heterozygosity for the C282Y mutation (C282Y/wild-type) is generally associated with a normal or sometimes a slightly increased dietary iron absorption pattern [11]. Population studies have shown that among ethnic Danes, at least $0.4 \%$, or one in 250 are C282Y homozygous equivalent to more than 20,000 people in Denmark, and more than 500,000 people are heterozygous (C282Y/ wild-type) or compound heterozygous (C282Y/H63D) for the HFE-mutations [1]. Consequently, genetic hemochromatosis is the most prevalent genetic disorder/disease in the northern European population.

Hepcidin, which is produced in the liver, is a "master regulator" of body iron homeostasis, and one of its principal functions is to inactivate ferroportin, which regulates iron transport out of the cells (efflux) through the cell membrane in enterocytes, hepatocytes and macrophages [12,13]. Consequently, hepcidin inhibits intestinal iron uptake [12-14]. In hemochromatosis, because of a defective HFE-complex, the production/ activation of hepcidin is reduced, resulting in an increased intestinal iron uptake, which by and large is independent of the body's iron status. HFE-hemochromatosis is characterized by a low plasma hepcidin level and a condition termed "hepcidin 
insufficiency" $[1,12,14]$.

Body iron homeostasis is strictly regulated through the complex mechanisms of dietary intestinal iron uptake [10, 1215], because humans have no specific mechanisms, by which body iron excretion can be regulated. Basal or obligatory body iron losses are relatively small, approximately $0.9-1.2 \mathrm{mg} /$ day in both men and women $[16,17]$ corresponding to approximately $360 \mathrm{mg} /$ year. However, many subjects with hemochromatosis can have an iron absorption in the range of $2-4 \mathrm{mg} /$ day [7-9]. Therefore, surplus body iron is most efficiently removed by repeated blood-lettings (phlebotomy) of $400-500$ $\mathrm{mL}$, each containing $240-250 \mathrm{mg}$ iron $[1,18]$. In the induction phase of the treatment, patients are phlebotomized weekly or every other week until serum ferritin has declined to $50-100$ $\mu \mathrm{g} / \mathrm{L}$. In the following maintenance phase of the treatment, phlebotomy is performed on an as needed basis, usually two to four times a year maintaining ferritin around $50-100 \mu \mathrm{g} / \mathrm{L}$ [1].

In hemochromatosis, body iron overload originates from an excessive absorption of food iron. Therefore, in theory, consuming a diet void of iron or with a low iron content could down-regulate the rate of body iron accumulation. Another important factor is the bioavailability of the iron in the food as well as the balance of promoters versus inhibitors of iron absorption in the meal. However, the effects of well-structured dietary interventions in hemochromatosis have not been investigated in adequately large, prospective, controlled studies [9].

Yet, studies of population subgroups with specific dietary habits have shown that the content and the chemical form of iron in the diet has a definite influence on body iron status. Vegetarians and vegans in general have a low body iron status, and women in the reproductive age often have iron deficiency $[19,20]$, despite that vegetarian diets contain more iron than omnivorous diets. A cross-over study showed that total and fractional iron absorption was significantly lower in a vegetarian diet than in a meat-rich diet [21]. Overall, a Western-type vegetarian diet has a low iron bioavailability ranging from $5 \%$ to $12 \%$ [22]. Many persons/patients with hemochromatosis express a high interest in being informed of dietary measures and recommendations that can reduce iron uptake and body iron accumulation. At the present time, this is in fact the only way in which patients can "actively" cooperate in the management of their iron overload.

The purpose of this review is to propose dietary measures that may reduce food iron uptake in persons/patients with iron overload. The dietary recommendations are based on the existing evidence-based knowledge of the different nutrients and compounds that influence iron uptake from the diet, recently published in a review paper [10]. However, the effect of the recommendations has not yet been investigated or evidencebased in clinical trials in persons with iron overload.

\section{Methods}

This review is based on literature searches in the PubMed and Google Scholar databases as well as literature references cited in published articles, review papers and books on metabolism and iron absorption [10]. Search terms included "hemochro- matosis AND diet". The elaboration of the dietary recommendations is based on the previous paper on the influence of nutrients and food compounds on intestinal iron absorption [10]. The dietary analyses and recommendations in this paper are based on the Western type of diet targeting populations in middle and northern Europe.

\section{Iron intake and absorption}

\section{Dietary iron intake}

The composition of the diet concerning the content of iron and the content of inhibitors/promoters of iron absorption has a significant impact on the development of clinically overt hemochromatosis. This is evident in the gender-specific difference in the prevalence of preclinical and clinical hemochromatosis. Although the HFE-mutations occur with the same frequencies in men and women, preclinical and clinical hemochromatosis is much more prevalent in men than in women and presents at a younger age in men compared to women [1]. As an example, the recommended dietary iron intake in men in Denmark is 9 $\mathrm{mg}$ /day [23], but Danish men have a median dietary iron intake of $12.7 \mathrm{mg} /$ day (10-90 percentile: 8.3 - 18.0) [24], indicating that approximately $88 \%$ have an intake, which is above the recommended intake. A review of dietary iron intake in men in European countries has recently been published [25], displaying the same pattern with an excess dietary iron intake in the various countries. Furthermore, men have a distinctly higher intake of meat [24-26] and alcohol [24, 25] than women, both factors, which promote iron uptake and increase the rate of body iron accumulation.

Conversely, in Danish women of reproductive age, the recommended iron intake is higher, $15 \mathrm{mg} /$ day [23], due to the extra physiological iron losses at menstruation [27] and pregnancies [28]. Danish women in the reproductive age have a median iron intake of $9.7 \mathrm{mg} /$ day (5-95 percentile: 5.6 - 14.5) $[24,29]$, indicating that $95 \%$ of the women have an intake below recommended intake. A review of dietary iron intake in women in European countries has recently been published [29], displaying the same pattern of iron intake in the various countries.

\section{Two forms of iron in the foods}

In the foods there are two main forms of iron: 1) Inorganic iron including nonheme iron consisting of mostly ferric iron $\left(\mathrm{Fe}^{3+}\right)$ and some ferrous iron $\left.\left(\mathrm{Fe}^{2+}\right) ; 2\right)$ Organic iron consisting of mainly heme iron from animals and ferritin iron from animals and plants. Most of the iron in the average meals is inorganic ferric iron, which is chemically relatively non-reactive. However, to be absorbed, ferric iron must be reduced to ferrous iron by either gastric acid $\mathrm{pH}$, reducing components in the meal or by the ferric reductase enzyme duodenal cytochrome $\mathrm{b}$, which catalyzes the reduction of $\mathrm{Fe}^{3+}$ to $\mathrm{Fe}^{2+}$, before the ferrous iron can be taken up in the enterocytes by the protein dimetal transporter-1-pathway $[10,13]$. The bioavailability of 
Table 1. The Most Important Promoters and Inhibitors of Nonheme Iron Absorption Adapted From [10]

\begin{tabular}{ll}
\hline Promoters & Inhibitors \\
\hline Gastric acid & Gastric acid inhibitors \\
Organic acids: ascorbic acid, lactic acid, tartaric acid & Oxalic acid - oxalates? \\
& Phytic acids - phytates \\
\hline Animal proteins: meat factors & Polyphenols \\
Heme: heme iron & Soya bean proteins \\
Sugar: fructose & Milk proteins \\
Alcohol: ethanol & Egg white proteins and egg yolk proteins \\
& Calcium: also inhibits heme iron absorption \\
\hline Ginger: gingerols? & \\
\hline Turmeric: curcumin depressing hepcidin expression? & Turmeric: curcumin forming chelates with iron? \\
\hline
\end{tabular}

nonheme iron in the Western-type diet is about 5-12\% [30] and absorption is highly dependent on the influence of the various promoters/inhibitors of absorption in the meal [10]. In the Western-type diet, $80-95 \%$ of the iron consists of inorganic, nonheme ferric iron $[25,29,30]$.

The organic ferric iron contained in the ferritin molecule, i.e., from animal- and plant foods, is released from within the ferritin shell by the gastric acid $\mathrm{pH}$ as well as by cooking. It enters the common nonheme iron pool in the meal and is absorbed as other nonheme iron compounds [31,32].

Heme iron, which is ferrous iron present in hemoglobin in the red blood cells and in myoglobin in the myocytes, is absorbed within the intact protoporphyrin molecule in a separate pathway [10]. Absorption of heme iron is three-fold to fourfold more efficient than of inorganic ferric nonheme iron [10]. Furthermore, heme iron absorption is quite independent of the effects of various promoters/inhibitors of iron absorption in the food matrix, except for calcium, which inhibits both heme and nonheme iron absorption $[10,33]$. In the Western diet, heme iron constitutes approximately $10-20 \%$ of the total iron in the whole meal $[25,29]$. Even though heme iron constitutes a minor fraction of total iron intake, it has a clear impact on body iron status due to its high absorption rate combined with the presence of "meat factors" [10]. Heme iron is thus the "super" iron for normal persons, but the "poisonous" iron for persons with hemochromatosis.

\section{Iron content in nutrients and whole meals}

In most European countries, the national food authorities have elaborated nutrition guidelines and food composition tables of the various nutrients in the specific country, which can be accessed on the internet $[25,29]$. It is therefore possible for dieticians and laymen to make an estimate of the iron content in specific nutrients and in whole meals. However, food composition tables should be considered as estimates and not as the definitive truth. The iron content of vegetables, fruits, berries, grains, pulses and legumes can vary considerably dependent on the specific subtype of vegetable, the iron content of the soil, the use (or not) of iron containing fertilizers and the cli- matic conditions during growth. As an example, the iron content of soya beans may vary from $4.0 \mathrm{mg} / 100 \mathrm{~g}$ dry weight in USA [34] to $15.7 \mathrm{mg} / 100 \mathrm{~g}$ dry weight in Denmark [35]. The iron content in raw spinach varies from $2.0 \mathrm{mg} / 100 \mathrm{mg}$ in The Netherlands [36] to $2.7 \mathrm{mg} / 100 \mathrm{~g}$ in USA [34] and $4.5 \mathrm{mg} / 100$ $\mathrm{g}$ in Denmark [35].

\section{Promoters and inhibitors of iron absorption}

Table 1 summarizes the most important promoters and inhibitors of iron absorption [10]. To exert their effect on intestinal iron uptake, promoters and inhibitors should be consumed concomitantly with the iron containing meal.

\section{1) Promoters}

The most important intrinsic promoter of nonheme iron uptake is hydrochloric acid contained in the gastric acid with a low $\mathrm{pH}$, enhancing the reduction of ferric iron in foods to ferrous iron $[10,37]$. Persons with achlorhydria are prone to develop iron deficiency [38], and both treatments with gastric acid inhibitors as well as with antacids will inhibit iron absorption [37]. In contrast, the uptake of heme iron is not affected by the presence or absence of gastric acid [10, 33]. Among extrinsic promoters of nonheme iron uptake, some organic acids, primarily including ascorbic acid [10, 39, 40] and lactic acid $[10,41]$ are potent enhancers of iron absorption. Ascorbic acid is contained in plant foods, such as citrus fruits, berries, tomatoes, broccoli, cauliflower, Brussels sprouts, bell peppers, cabbage and spinach. Lactic acid is present in fermented food products, such as fermented vegetables, fermented grains, e.g., sourdough bread, and fermented dairy products, e.g., yogurt.

Meat factors contained in animal proteins are potent promoters of nonheme iron uptake, both of the iron contained within the meat itself, and also of the iron contained in the other nutritional components of a whole meal [10,42]. Alcohol from any source of drinks stimulates nonheme iron absorption from a meal in two ways: directly in the intestine $[10,43]$ and indirectly by down-regulating the expression/synthesis of hep- 
cidin in the liver [10, 44].

Small human studies investigating the influence of sugars on nonheme iron absorption have yielded conflicting results; some studies demonstrated improved iron bioavailability, while others found either no effect, or decreased absorption. For a review, see reference [45]. The most consistent finding is that fructose promotes nonheme iron absorption, possibly by chelating and/or reducing ferric iron to the ferrous form [46, 47]. The disaccharide sucrose is the most used sweetener in the Nordic countries, which in the intestine by the enzyme sucrase is split into glucose and fructose.

\section{2) Inhibitors}

Medicine comprising gastric acid inhibitors and antacids inhibit nonheme iron absorption [10,37].

The two most important groups of naturally occurring inhibitors in foods are phytic acids/phytates contained in plant foods, predominantly grains, bran, pulses, legumes and nuts $[10,48]$ and polyphenols contained in a plethora of plant foods such as tea, coffee, vegetables, fruits, berries and nuts [10, 49, 50]. Some plant proteins, such as soya bean proteins are also moderate to strong inhibitors of iron uptake [10,51]. Animal proteins from milk $[10,52]$ and egg $[10,53,54]$ have also been shown to inhibit iron absorption quite effectively.

Calcium is a well-known inhibitor of both nonheme [10, $55]$ and heme iron absorption $[10,56]$. Most of the calcium in the common diet comes from bovine milk dairy products and some from plant foods such as green leafy vegetables, e.g., spinach, broccoli, cabbage, and okra; some pulses and legumes, e.g., soya beans also contain appreciable amounts of calcium, about $277 \mathrm{mg} / 100 \mathrm{~g}$ raw weight $[10,34]$.

Oxalic acid present in many leafy plant foods, e.g., spinach, mangold, purslane and rhubarb, is a proven inhibitor of calcium absorption due to the poor solubility of calcium oxalate [57]. It has for many years also been perceived as a potent inhibitor of nonheme iron absorption. However, its role in iron absorption is now controversial due to the results of a recent human study showing no effect of potassium oxalate on nonheme iron uptake $[10,58]$. Clearly, further studies are needed to finally clarify the effect of oxalic acid. However, due to the high content of oxalic acid, which may cause renal stones consisting of calcium oxalate [57], the intake of spinach and rhubarb should be low and substituted with other green leafy vegetables with a lower content of oxalic acid, such as kale. Alternatively, oxalic acid in the food can be neutralized by adding adequate amounts of calcium chloride.

The popular and widely used spice turmeric, an essential component in yellow curry, contains the biologically active substance curcumin, having anti-oxidative and anti-inflammatory properties $[10,59]$ and being perceived by many nutritionists to inhibit nonheme iron uptake, and therefore recommended to persons with hemochromatosis and iron overload [60]. However, in a human study, turmeric had no influence on iron absorption, despite a high content of polyphenols [61]. New research has demonstrated that turmeric inhibits the synthesis of hepcidin in the liver $[10,62]$ and may therefore indirectly stimulate iron absorption. Consequently, recommending the intake of turmeric/curcumin to persons with iron overload is controversial and further studies are needed to clarify the role of curcumin in iron metabolism [10].

Ginger is another popular and widely used spice, but there exist no studies on the effect on nonheme iron uptake. Some authors suggest that ginger supplements may be beneficial for treatment of iron deficiency anemia when taken together with oral iron $[63,64]$. Until further studies are available, it is recommended that ginger should be used with moderacy in cooking foods, and ginger shots should be taken between meals.

\section{How should the diet be composed in persons with iron overload?}

Vegetarians in general have a low body iron status [19, 20], even though the iron content in their diet often is distinctly above the recommended intake [65-67]. The reason for this discrepancy is that all the iron contained in a diet based on plant foods is nonheme ferric iron, which basically has a poor availability and furthermore many plant foods are rich in compounds that inhibit iron absorption, e.g., phytates, polyphenols and some plant proteins (see above). Studies have also shown that iron absorption is significantly lower from a vegetarian diet than from a meat-rich diet [21]. This knowledge encourages to recommend a predominantly plant-based, semi-vegetarian style of diet also containing dairy products and eggs, a "veggie-lactoovo" style diet to persons with iron overload or predisposition to iron overload. The diet should be varied, and balanced to fulfill the demands for proteins, vitamins and minerals.

\section{Reducing the intake of heme iron and meat factors}

\section{1) Mammal and poultry meat}

In a standard diet, approximately $10-20 \%$ of the total iron content consists of heme iron, contained in animal meat together with meat factors $[10,25,29]$. Meat is a rich source of protein, containing $20-30 \mathrm{~g}$ protein $/ 100 \mathrm{~g}$, depending on the fat content [34]. The heme iron is present in the myoglobin and in the variable amount of hemoglobin in blood, which remains captured in the blood vessels in the muscles after butchering and exsanguinating the animals. The most widely consumed sorts of meat are pork, beef, veal, lamb and poultry. Both myoglobin and hemoglobin are red pigments that give the meat its red color, i.e., the redder the meat, the higher the content of myoglobin/hemoglobin and heme iron [68]. The content of myoglobin in the muscles increases with the age of the animal [68]. Most animals are butchered at a young age, varying from 2 months (chicken) to 3 months (pigs) and 6 - 10 months (calves and lambs). In Denmark, beef cattle is butchered after the age of $10-20$ months. Dairy cows are butchered after 65 - 68 months [67] and their meats have a high content of myoglobin and heme iron [68], the so-called "red meat", in contrast to the "white meat" from poultry, e.g., chicken breast.

Beef contains more total iron $(2.2 \mathrm{mg} / 100 \mathrm{~g})$ than veal $(1.5 \mathrm{mg} / 100 \mathrm{~g})$, leg of lamb (1.5 mg/100 g), pork chops (1.0 
$\mathrm{mg} / 100 \mathrm{~g})$ and chicken breast $(0.9 \mathrm{mg} / 100 \mathrm{~g})$ [35]. The iron content of the meat in the specific animal also varies between different muscle groups; the iron content in the red meat in chicken legs $(1.8 \mathrm{mg} / 100 \mathrm{~g})$ is twice as high as in the white meat in chicken breast; duck meat contains $1.2 \mathrm{mg}$ iron $/ 100 \mathrm{~g}$, while duck breast has a high iron content of $4.5 \mathrm{mg} / 100 \mathrm{~g}$ [35]. Ground beef is predominantly produced from old dairy cows [67] and therefore has a high content of heme iron. Of the total iron content, heme iron constitutes $83 \%$ in beef, $63 \%$ in pork chops and 33-44\% in chicken [36]. Mammals and birds killed by shooting are not exsanguinated, and game meat is therefore very rich in iron and should be avoided.

Offal, also called variety meats, pluck or organ meats, is the viscera and entrails of an animal. Offal and products containing blood, e.g., blood sausage have a high heme and nonheme iron content as well as meat factors and should be avoided by persons with hemochromatosis. As examples, the total iron content in pork offal is: in liver $13.4 \mathrm{mg} / 100 \mathrm{~g}$, liver pate $5.6 \mathrm{mg} / 100 \mathrm{~g}$, heart $6.0 \mathrm{mg} / 100 \mathrm{~g}$, kidney $3.3 \mathrm{mg} / 100 \mathrm{~g}$ and in blood sausage $16.2 \mathrm{mg} / 100 \mathrm{~g}$ [35]. Ideally, the consumption of meat should be as low as possible, and not be consumed on a daily basis. If the meal includes meat, the red meat must be avoided and the white meat from poultry, young pigs and young calves should be preferred and consumed in moderate quantities not more than two times per week.

\section{2) Fish meat}

In general, white fish meat has a low iron content, whereas the red meat from the big skipjack tuna contains myoglobin and has a higher iron content $[34,35]$. Fish meat has a high content of protein of $20-30 \mathrm{~g} / 100 \mathrm{~g}$ [34], equal to the content in mammal meat. Fish is therefore an important source of protein, and fat fish in addition contains essential fatty acids. The total iron content in lean fish meat is $0.2 \mathrm{mg} / 100 \mathrm{~g}$ in cod, $0.1 \mathrm{mg} / 100 \mathrm{~g}$ in plaice and $0.8 \mathrm{mg} / 100 \mathrm{~g}$ in redfish, and in fat fish meat 0.2 $\mathrm{mg} / 100 \mathrm{~g}$ in farm raised salmon, $0.8 \mathrm{mg} / 100 \mathrm{~g}$ in mackerel, $0.7-1.3 \mathrm{mg} / 100 \mathrm{~g}$ in herring and $1.6 \mathrm{mg} / 100 \mathrm{~g}$ in tuna [34, 35]. Cod fillet contains no heme iron, while $30-40 \%$ of the iron content in the other fish species is heme iron [36]. Fish meat in addition contains meat factors $[42,69]$, so the iron has a quite good bioavailability. For persons with iron overload, it may therefore be an advantage to replace the intake of mammal meat with white poultry meat and lean fish meat from cod, plaice, and redfish, as well as occasional fat fish meat from mackerel and salmon two to four times per week. A "veggielacto-ovo-poultry-pescetarian" style diet will also ensure a sufficient intake of proteins and essential fatty acids.

\section{3) Shellfish}

Shellfish like blue mussels, oysters, crabs and lobsters are generally rich in iron [25] and should be avoided or consumed in small quantities, and all shellfish should be well cooked. Raw mussels including oysters can harbor bacteria like Vibrio vulnificus, which may cause severe food poisoning infections both in apparently healthy persons [70] but especially in patients with chronic diseases, and liver affection, e.g., hemochromatosis [71, 72].

\section{Importance of getting enough protein}

Healthy persons are recommended to consume $0.8-1.0 \mathrm{~g}$ protein/kg body weight per day [23]. In a phlebotomy of $500 \mathrm{~mL}$ blood, 130 - $140 \mathrm{~g}$ of protein are lost, equivalent to 2 days recommended intake. During the induction phase [1] where patients are phlebotomized weekly or every other week, it is essential to compensate for the extra protein losses and increase the protein intake to approximately $1.3-1.5 \mathrm{~g} / \mathrm{kg}$ body weight per day.

\section{1) Animal proteins}

White poultry meat and white fish meat are recommended good sources of protein (see above). Eggs contain approximately $14 \mathrm{~g}$ protein/100 g [34], so one to two eggs a day can be a source of protein, unless egg yolk should be avoided due to hyperlipidemia and/or cardiovascular disease. Milk contains approximately $3.4 \mathrm{~g}$ protein $/ 100 \mathrm{~mL}$ and harbors all the nine essential amino acids, so drinking $1 \mathrm{~L}$ of low-fat milk will provide the body with $34 \mathrm{~g}$ protein [34]. Low-fat, proteinrich lactic acid fermented milk products such as the Icelandic inspired "Skyr" or yoghurt containing up to $11 \mathrm{~g}$ protein/100 $\mathrm{g}$ are good sources of additional protein. The lactic acid contained in fermented milk does not appear to enhance iron absorption, i.e., cannot overrule the inhibiting effects of calcium and milk proteins [10]. The diet can also be supplemented with whey protein powder in an appropriate amount, e.g., 30 - 40 g per day. The lactic acid in fermented milk does not increase iron absorption, because the iron content in milk is negligible $[34]$, and both the proteins $[10,52]$ and the calcium contained in milk $[10,55]$ inhibit iron absorption.

There are a plethora of protein drinks or shakes on the market. However, most of these contain added minerals often including iron, and vitamins often including vitamin C. It is important to check the declaration and avoid products containing iron and vitamin $\mathrm{C}$.

\section{2) Plant proteins}

Pulses and legumes, especially beans, contain between $21 \%$ and $25 \%$ proteins by weight, which is much higher than the protein content in other vegetables [34-36]. The high protein content is due to the atmospheric nitrogen capturing activity occurring in the root nodules in symbiosis with Rhizobia bacteria [73]. Especially kidney beans, soya beans and soya bean derived products have a high protein content of 24 - 36 g protein/100 g [34] and can be consumed on a daily basis, in order to increase protein intake. Soya bean milk has almost the same protein content as bovine milk, $3.3 \mathrm{~g} / 100 \mathrm{~mL}$ [34].

Tempeh is a traditional Indonesian product that is based on 
fermented soya beans. It is made by a natural culturing and a controlled fermentation process with Rhizopus oligosporus that binds soya beans into a cake form. It has a high protein content of $18 \mathrm{~g} / 100 \mathrm{~g}$ [34]. Tofu, also known as bean curd, is a food prepared by coagulating soya bean milk and then pressing the resulting curds into solid white blocks of varying softness. The protein content is about $8 \mathrm{~g} / 100 \mathrm{~g}$ [34]. Some species of soya beans may be rich in iron, probably due to the culturing conditions [10]. However, there appear to be no reasons for not using soya bean protein supplements, as both soya bean protein, and the high content of intrinsic phytate as well as calcium will inhibit iron absorption [10]. A diet rich in soya bean products containing native phytate significantly decreases body iron status (serum ferritin) in postmenopausal women [74].

\section{Grains and cereals - choose whole grain products}

Whole grains contain phytic acids/phytates [10, 48], of which the major part is present in the shell parts of the grain, germ and bran. It is therefore important to choose flour-based products, which contain a high proportion of whole grain flour, e.g., whole grain bread and whole grain pasta and other products based on whole grain flour. Likewise, cereals based on whole grain should be preferred.

When baking at home, whole grain should be used and it is also possible to increase the content of phytates by adding extra wheat bran to the flour. It is important to use yeast-based fermentation of the dough and not lactic acid fermentation as in sourdough [10]. Lactic acid is a potent promoter of iron absorption by itself, due to its acidity $[10,41]$. Furthermore, lactic acid fermentation by itself produces phytase, and can activate the dormant intrinsic phytase activity in the flour [75], two mechanisms, which can reduce the phytate content in grains [76]. When purchasing industrially baked bread and other grain products, it is important to check the declaration concerning the content of whole grain flour and use of sourdough as well as whether the flour or bread has been enriched with iron.

\section{Abstinence of alcohol}

\section{1) Alcohol}

Regular consumption of alcohol predisposes to iron overload, depending on the amount consumed, and especially if the consumption is higher than recommended by the health authorities $[10,43,44]$. In population studies, there are clear positive associations between the quantity of alcohol intake and the iron status marker serum ferritin, both in men and women. An increased alcohol intake is associated with an increase in ferritin [77-79]. In persons with $H F E$-hemochromatosis, alcohol consumption increases both the biochemical and clinical disease expression, as well as the risk of liver cirrhosis and liver cancer [80].

Alcohol seems to increase ferric iron absorption from the meal, possibly due to the stimulating effect on gastric acid secretion [81]. However, the enhancing influence of alcohol on iron absorption is more likely due to its inhibition of hepcidin expression/synthesis in the liver $[10,44]$. Alcohol induced decrease in hepcidin synthesis has been demonstrated both in patients with alcoholic liver disease [44], as well as in animal studies [10]. Both acute and chronic alcohol exposures suppress hepcidin expression in the liver [82]. Persons with hemochromatosis a priori have low hepcidin levels, but it has not yet been evaluated whether alcohol consumption may contribute to a further reduction of hepcidin expression in these patients.

\section{2) Wines}

White wines and red wines contain varying amounts of iron depending on the grape varieties, the iron content in the soil in which the grapes are cultured, the iron content in fertilizers and the wine production processes. The average iron content in white wine is $3 \mathrm{mg} / \mathrm{L}$ and in red wine is $5 \mathrm{mg} / \mathrm{L}$ [34]. Furthermore, wines contain various amounts of phenols and polyphenols, including tannins, depending on the grape varieties, growth conditions including climatic conditions, fertilizers and the wine production processes.

White wines have a significant increasing effect on food iron absorption, which is even higher than can be explained solely by its alcohol content [83]. This is probably due to its low content of phenols and tannins and its high content of organic acids, as well as the low $\mathrm{pH}$, which all promote iron absorption $[10,83]$.

Red wines also contain organic acids but have a higher $\mathrm{pH}$ than white wines. The coloring in red wines is due to their content of phenols and tannins, which inhibit food iron absorption $[10,49,50]$. The higher the content of phenols and tannins, the higher the inhibition of iron uptake. If occasionally, red wine is consumed, choose heavy bodied red wines with a high content of tannins; enjoy with a selection of cheeses, which due to their low content of iron and their high contents of milk protein and calcium, inhibit iron absorption [10]. Do not drink wine with a selection of cold cuts and sausages, which due to their high content of heme- and nonheme iron and meat factors, stimulate iron absorption.

The Danish Health Authority recommends a maximum of seven standard drinks (each containing $12 \mathrm{~g}$ alcohol) per week in healthy women and a maximum of 14 standard drinks per week in healthy men [84]. This amount of intake is, however, not recommended to persons with hemochromatosis. Considering the present evidence, in hemochromatosis, it is clearly best to abstain from alcohol, or at least the consumption should be restricted to a minimum, and alcoholic beverages should be replaced by their non-alcoholic counterparts.

\section{What to drink with meals and between meals?}

The beverages consumed with the meal can significantly influence the absorption of food iron, i.e., either increase or decrease absorption. Drinking alcoholic beverages increases iron absorption (see above). Drinking fruit juices, both processed and fresh, containing vitamin $\mathrm{C}$, and having a low $\mathrm{pH}$ due to 
the content of organic acids and possibly a high content of sucrose and/or fructose will significantly increase iron uptake (see above). Consequently, this kind of beverages should not be taken with the meals. Fresh fruit juices are healthy foods containing antioxidants, vitamins and minerals; they should not be avoided but instead consumed between the meals. Milk proteins and calcium both inhibit food iron absorption [10], so drinking a glass of milk with the meals may be beneficial for persons with iron overload.

Recommended beverages to the meals are green- or black tea, coffee, low-fat milk, or water. In Denmark, tap water is potable and contains no iron. Some bottled mineral water may contain iron, check the declaration.

Polyphenols contained in tea and coffee are strong inhibitors of iron absorption [10]. The infusion of $1.5 \mathrm{~g}$ of the black Ceylon Wewesse tea contains 90 - $100 \mathrm{mg}$ polyphenols [85], so a standard cup or mug $(250 \mathrm{~mL})$ of this tea contains about 90 - $100 \mathrm{mg}$ polyphenols. In general, the polyphenol content in a cup of green- or black teas is depending on the variety of tea, the processing of the tea leaves, the type of brewing (tea leaves or tea bags) and the strength (grams of tea leaves per $\mathrm{mL}$ of water) of the infusion $[85,86]$. One of the few controlled, nutritional studies in persons with hemochromatosis showed that regular tea drinking with the three daily main meals decreased food iron absorption on the long term, resulting in a reduced yearly rate of phlebotomies in the maintenance phase of the disease [85].

In patients with impaired liver function, i.e., significantly elevated liver enzymes, liver fibrosis or liver cirrhosis, heavy green tea drinking and/or the consumption of green tea extract food supplements may induce severe liver damage, and in some even acute liver failure [87]. Therefore, no more than three cups of green tea should be consumed per day and food supplements of green tea extract should be avoided.

Coffees (with caffeine) also contain polyphenols, varying from 30 to $300 \mathrm{mg}$ per cup of coffee, depending on the variety of coffee beans, the processing of the beans and the strength of the coffee brew (grams of coffee beans per mL of water) [88]. Furthermore, regular coffee drinking appears to be beneficial for the overall liver function, see review [89]. "Moderate coffee consumption may be related to a slower progression of chronic liver disease. Patients who consumed a higher quantity of coffee have been found to display a milder course of fibrosis, especially in those with alcohol related liver disease. The association between moderate coffee consumption and a slower rate of fibrosis has also been seen in patients with hepatic fibrosis, cirrhosis, non-alcohol related liver disease and hepatitis" [89]. Likewise, regular coffee drinking has a protective effect against non-alcoholic fatty liver disease [90]. In conclusion, regular coffee drinking with meals (three to four cups daily) can replace regular tea drinking with meals, possibly with benefits especially in patients with impaired liver function, liver fibrosis or liver cirrhosis.

\section{Use the right cooking utensils}

Nowadays, most cooking utensils, like pots and pans/skillets have a non-stick coating, and no metal is released from the uten- sils during the cooking process, whether boiling or frying. However, previously there was a widespread use of cast iron pots and pans without coating, which still are used by many people, depending of the regional cooking habits. Iron utensils release iron during the cooking process, especially if the prepared foods are acidic with a low $\mathrm{pH}$. As an example, the iron content increased from $0.6 \mathrm{mg}$ to $5.7 \mathrm{mg} / 100 \mathrm{~g}$ in spaghetti sauce after being cooked in a cast iron pot [91]. Consequently, the message is clear: do not use uncoated iron utensils in cooking!

\section{Vitamins and minerals}

\section{1) Vitamins}

In healthy people, the needs for vitamins are usually covered by eating a healthy, varied and balanced diet [92]. In hemochromatosis, during the induction phase, the patients are phlebotomized with 1 week or 2 weeks intervals. Depending on the magnitude of iron overload at diagnosis, the induction treatment can vary greatly, e.g., from 6 to 24 months. Frequent phlebotomies are associated with loss of various vitamins in the blood, but none has so far measured or tried to estimate these losses.

Some Danish centers monitor the blood concentrations of vitamin $\mathrm{B}_{12}$, folate and vitamin $\mathrm{D}$ during the induction treatment of hemochromatosis patients and prescribe vitamin supplements according to the vitamin levels. Although not confirmed in controlled studies, common sense, the benefit of doubt, and the absence of side effects concerning vitamin intake motivate the author to consider a regular daily intake of multivitamin tablets in the induction phase, in order to secure an adequate body "vitamin status".

In the maintenance phase, where patients are phlebotomized two to four times in a year, the intake of multivitamin tablets may according to the author's suggestion be reduced to three times a week or alternatively to a daily intake in 1 week or 2 weeks in connection with phlebotomies. The multivitamin tablets should be checked for having an adequate content of the various vitamins, especially vitamin $\mathrm{D}_{3}$ and vitamin $\mathrm{E}$. It is also important to emphasize that the tablets should be taken between meals, due to their content of vitamin C. According to the Nordic nutrition recommendations, the recommended intake of vitamin $C$ in adults is $75 \mathrm{mg} /$ day [23]. Therefore, the multivitamin tablets should not contain more than $200 \mathrm{mg}$ vitamin C per day, as suggested by the Iron Disorders Institute [93].

Osteopenia and osteoporosis occur frequently; among patients with clinical hemochromatosis, $41 \%$ have osteopenia and $25 \%$ osteoporosis [1]. The frequency of osteoporosis increases with increasing iron overload [1], and it is therefore important to have an adequate intake of vitamin $\mathrm{D}_{3}$ (and calcium, see mineral section below) to prevent bone decalcification [94]. The plasma vitamin D level should be checked for vitamin deficiency/adequacy. The recommended intake of vitamin $\mathrm{D}_{3}$ according to the Nordic nutrition recommendations is $10 \mu \mathrm{g}$ /day for adults and $20 \mu \mathrm{g}$ for adults above 75 years [23]. If the multivitamin tablets have a lower content of vitamin $\mathrm{D}_{3}$, additional vitamin $\mathrm{D}_{3}$ supplements should be taken; 
Table 2. Guidelines for a Healthy Diet, Targeted to Healthy People Adapted From the Nordic Nutrition Recommendations 2012 [23]

Scientific evidence indicates that a micronutrient- and fiber-dense diet should be adopted to promote health and wellbeing in Nordic populations.

The diet should include: 1) Natural fiber-rich foods; 2) Vegetables: dark-green leaves, fresh peas, cabbage, onions, root vegetables and fruiting vegetables; 3) Pulses, legumes, fruits, berries, nuts, seeds, and whole grains as well as fish and seafood, vegetable oils, vegetable oil-based spreads and low-fat dairy products.

Such a dietary pattern, especially if low in energy density and combined with a physically active lifestyle, will reduce the risk of overweight.

In contrast, dietary patterns characterized by high intakes of red meat, processed meat and food products made from refined grains and sifted flour as well as those high in sugar, salt and saturated fatty acids and trans-fatty acids are associated with adverse health effects.

in most persons, a supplement of $20 \mu \mathrm{g}$ /day will be sufficient. Furthermore, a bone mineral (dual energy X-ray absorptiometry (DEXA)) scan should be performed, in order to check for osteopenia/osteoporosis [1].

Vitamin E (d-alfatocoferol) is an important antioxidant [95]. The recommended intake of vitamin E according to the Nordic nutrition recommendations is $10 \mathrm{mg} /$ day for men and $8 \mathrm{mg} /$ day for women [23], while the US National Institutes of Health recommend a higher dose of $15 \mathrm{mg}$ /day in both genders [95]. Many multivitamin tablets contain 20 - $30 \mathrm{mg}$ of vitamin $\mathrm{E}$, which is adequate. If necessary, an extra vitamin E supplement should be taken.

\section{2) Minerals}

In healthy people, the needs for minerals are usually covered by eating a healthy, varied and balanced diet [92]. Many multivitamin tablets also contain the essential minerals (multivitamin-multimineral tablets). Taking combined multivitaminmultimineral tablets will cover the need for essential minerals in most people.

Selenium is an essential micronutrient, which is a component of the important antioxidant enzymes glutathione peroxidase and thioredoxin reductase [23]. The recommended intake of selenium according to the Nordic nutrition recommendations is $60 \mu \mathrm{g} /$ day and the intake must not exceed $300 \mu \mathrm{g} /$ day [23]. Check whether the selenium content in the multivitaminmultimineral tablets is adequate, i.e., $60 \mu \mathrm{g}$ or higher; if not, an extra selenium supplement may be indicated.

Due to the high risk of osteoporosis, it is important to have an adequate intake of calcium (and vitamin $\mathrm{D}_{3}$, see vitamin section above). The recommended intake of calcium according to the Nordic nutrition recommendations is $800 \mathrm{mg} /$ day [23]. The richest food sources of calcium are milk and milk products including cheese [23]. One liter of milk contains 1,200 mg calcium [34]. Depending on the consumption of milk products, calcium supplement should be taken in the form of calcium citrate. Calcium tablets are marketed with and without additional vitamin $\mathrm{D}_{3}$. As calcium inhibits iron absorption [10], calcium supplements should be taken with meals.

\section{Anti-oxidative and anti-inflammatory compounds}

In hemochromatosis, the surplus amount of iron in the cells and organs induces oxidative stress by the formation of free radicals through the Fenton reaction, which is assumed to be the basis for inflammation, cell necrosis and the development of connective tissue and fibrosis in various organs [1]. Antiinflammatory and anti-oxidative diets [96] have become increasingly popular in recent years and are promoted by many nutritionists and rheumatic associations [97]. The concept is that a high intake of anti-oxidative-rich macronutrients and a favorable balance between omega- 6 and omega- 3 fatty acids in the diet can decrease the expression of inflammatory genes $[96,98]$. Omega-3 fatty acids (eicosapentaenoic acid plus docosahexaenoic acid) have both anti-oxidative [99] and antiinflammatory properties $[96,98]$, and exert favorable effects on inflammatory arthritis, e.g., rheumatoid arthritis [96, 98].

An anti-inflammatory diet should contain adequate amounts of omega-3 fatty acids at the level of a total of $2-3$ $\mathrm{g}$ of eicosapentaenoic acid (EPA) and docosahexaenoic acid (DHA) per day [96]. Even a high daily intake of fat fish can hardly fulfill these requirements, so it is necessary to take supplementary fish oil capsules with the meals [96]. Furthermore, an anti-oxidative diet should be rich in colorful, non-starchy vegetables and fruits, which will contribute adequate amounts of polyphenols to help inhibit nuclear factor kappa beta, a primary molecular target of inflammation, and activate 5' adenosine monophosphate-activated protein kinase that plays an important role in cellular energy homeostasis [96].

From a empirical point of view, it seems likely that an anti-oxidative/anti-inflammatory diet comprising tea/coffee and many colorful vegetables, fruits and berries containing plant pigments acting as natural antioxidants, such as polyphenols (flavonoids and anthocyanins), as well as carotenoids [96], and providing adequate amounts of vitamin $\mathrm{E}$ and selenium, as well as anti-inflammatory supplements of omega-3 fatty acids [96], will be of benefit for persons with hemochromatosis. However, until now no systematic studies have been performed to explore this issue.

\section{Official dietary recommendations in the Nordic Countries}

The Nordic nutrition recommendations 2012 by the Nordic Council of Ministers [23] and the official Danish dietary recommendations 2021 [92] have many features in common with the composition of anti-inflammatory and anti-oxidative diets. The Nordic nutrition recommendations [23] are shown in Table 2 .

The official Danish dietary recommendations 2021 [92] shown in Figure 1 and Table 3 are targeted towards healthy 


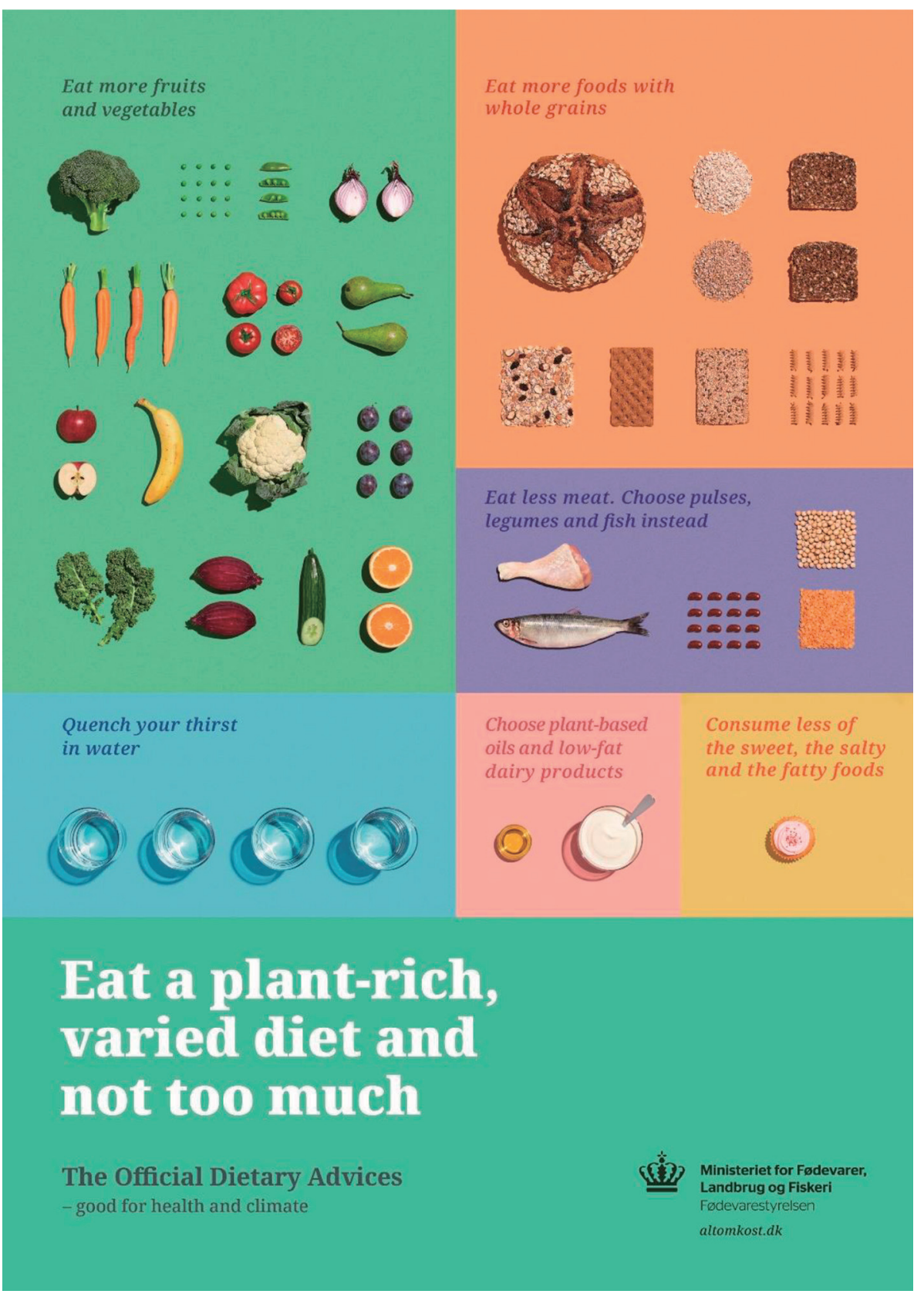

Figure 1. The seven official Danish dietary recommendations 2021 [92] visualized in a poster.

Table 3. The Seven Official Danish Dietary Recommendations 2021 From the Danish Veterinary and Food Administration [92, 100]

1. Eat a plant-rich diet with varied foods, do not eat too much.

2. Eat more vegetables and fruits, corresponding to approximately $600 \mathrm{~g}$ vegetables and fruits per day.

3. Eat less meat from mammals, at most $350 \mathrm{~g}$ per week. Choose pulses, legumes, poultry and fish. Eat fish at least twice a week as main course, and several times a week on an open sandwich, at least $350 \mathrm{~g}$ fish per week of which $200 \mathrm{~g}$ should be fat fish.

4. Eat foods with whole grains, at least 75 - $100 \mathrm{~g}$ whole grains per day.

5. Choose vegetable oils, rapeseed and olive oil, and low-fat dairy products.

6. Eat foods with less sugar, less salt and less fat.

7. Quench your thirst in water, instead of in soda, processed juices, or alcoholic beverages. Drink water both with the foods and between meals. 
Table 4. Proposed Dietary Recommendations for Persons With Hemochromatosis Adapted From the Official Danish Dietary Recommendations $2021[92,100]$

1. Choose a vegetarian, semi-vegetarian or flexitarian diet. A "veggie-lacto-ovo-poultry-pescetarian" diet seems optimal. Eat varied foods, not too much. Avoid iron enriched foods and iron supplements. Be physically active $30-60$ min daily.

2. Eat many vegetables and fruits - corresponding to at least $600 \mathrm{~g}$ of vegetables and fruits daily; at least half of this must be vegetables. Choose protein rich pulses or legumes, e.g., white-, kidney- or soya beans. Fresh fruits should be eaten between meals.

3. Abstain from red meat from mammals and choose lean, white meat from poultry. Avoid processed meat. Avoid offal, blood containing foods and game meat. Eat no more than $200 \mathrm{~g}$ meat from preferably poultry per week, which equates to two dinners per week. Choose fish, eggs, vegetables and protein rich legumes the other days. Eat sustainably sourced fish two to four times a week as main course, and several times a week on an open sandwich - at least 350 - $500 \mathrm{~g}$ fish per week, of which $200 \mathrm{~g}$ must be fat fish.

4. Choose whole grain products in cereals and bread. Eat at least 75 - $100 \mathrm{~g}$ whole grains per day. Avoid iron enriched grains. Choose nonsourdough, yeast-fermented bread with at least $50 \%$ whole grain. Add wheat bran to the whole grain flour when baking at home.

5. Choose vegetable oils, rapeseed- and olive oil, and low-fat dairy products. Low-fat milk, and sour milk products with maximum $0.2-0.7 \%$ fat, and cheese with maximum $17 \%$ fat.

6. Eat less sugar. Choose whole foods and foods with minimal processing and none or little added sugar. Eat less salt - buy foods with low salt content and cut down the use of salt when cooking.

7. Abstain from alcohol. Quench your thirst in water, instead of in soda, processed juices, or alcoholic beverages. Fruit juice should be consumed between meals. Drink green- or black tea, coffee, or low-fat milk with meals, alternatively water or non-alcoholic beer.

people and do not contain specific dietary instructions for persons with genetic hemochromatosis and iron overload. Compared with the previous official Danish dietary recommendations in 2013, there is a greater emphasis on plant-rich, low-meat, fish-rich and climate-friendly diets.

The general tendency from the national food authorities and nutritionists in Denmark and other European countries is to encourage people to eat less meat and more plant-based foods [100], in order to make the diets more climate-friendly. As the meat production generates formation of carbon dioxide and ammonium, one of the measures to reduce carbon dioxide emission to the atmosphere [101] and nitrogen and phosphorous to the environment [102], is to cut-down meat production especially from mammals (beef, pork, lamb) and to a lesser extent from poultry [101]. Plant-based meat substitutes are produced to an increasing extent by the food industry and consumed both in the households and in eating-out facilities. In Denmark, the number of vegetarians, vegans and flexitarians has been steadily increasing from almost zero in 2010 to $2.5 \%$ of the population in 2019 [103], and in recent years, $30 \%$ of the population has diminished their consumption of meat [104].

\section{Dietary recommendations for persons with hemochroma- tosis}

It is important to stress that the following recommendations are not based on controlled dietary studies but are empirically based on the current knowledge of the iron content in foods and the mechanisms of intestinal food iron absorption [10]. The proposed recommendations shown in Table 4 are adapted from the official Danish dietary recommendations 2021 [92, 100]. The modifications express the views of the author.

Figure 2 shows the Danish food pyramid created by Coop Danmark A/S in 1976 and last updated in 2011 [105]. The recommendations are also elaborated to be climate-friendly. Ap- parently, the recommendations are close to those of an antiinflammatory and anti-oxidative diet, and the food pyramid also appears to be suitable for persons with hemochromatosis with a few modifications.

\section{Discussion}

The diet recommendations in this paper for persons with genetically, dietary-induced iron overload, are based on our present knowledge of the mechanisms, which control intestinal iron absorption [10]. The interest for dietary interventions in hemochromatosis has mostly been based on the layman aspect, and well-performed, prospective, randomized studies that specifically evaluate the effect of dietary interventions have not been reported [9].

Clinics managing persons with hemochromatosis in Denmark [106] and probably other European countries [9] give little or no emphasis on the composition of the diet with general advices such as "eat your usual diet but limit intakes of red meat and alcohol" or "eat a healthy and varied diet" [9] and only few Danish patients are given specific advices by a dietician [106].

The composition of the diet has a distinct influence on the expressivity (serum ferritin and serum transferrin saturation levels) of the $H F E$-variant phenotypes in Danish men. The expressivity was enhanced by consumption of alcohol and meat and decreased by consumption of milk and eggs [107]. Depending on the degree of dietary interventions and the penetrance of the genetic disorder, dietary measures aiming to restrict the absorption of dietary iron in patients with hemochromatosis in the maintenance phase might reduce the annual amount of blood-letting by an estimated 0.5 - 1.5 L, i.e., by three to four phlebotomies [9].

The Danish Hemochromatosis Association [108] performed a dietary survey, which revealed that all patients were omnivorous, consuming mammalian and avian meat several 


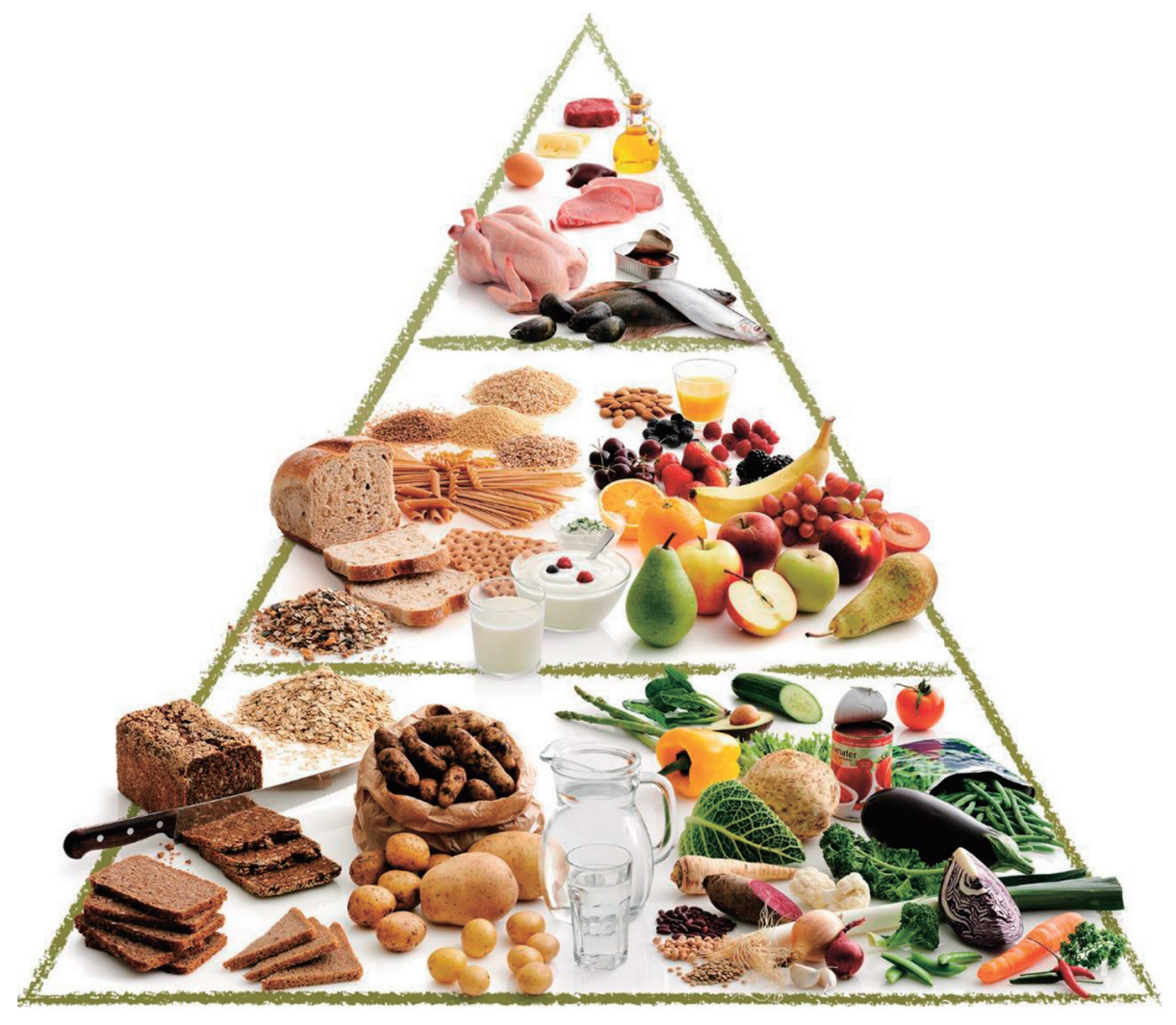

Figure 2. The Danish Coop food pyramid 2011 [105] shows the recommended consumption of foods in healthy persons during a 14-day period. Eat most foods from the bottom, less from the middle and least from the top shelf. Modifications for persons with hemochromatosis. Top shelf: Do not eat beef or pork, but white poultry meat, no more than twice a week. Do not eat liver or products containing liver (liver pate, liver spread and liver pastry) or other offal. Do not eat products containing blood, e.g., blood sausage and game meat. Eat fish two to four times per week. Avoid shellfish. Eggs, one or two per day, are allowed, unless hyperlipidemia or cardiovascular disease is present. Middle shelf: Consume low-fat milk products including cheese. Drink milk with meals. Fruits, berries and juices rich in vitamin $\mathrm{C}$ and organic fruit acids should be consumed between meals. Bottom shelf: Drink a cup of green- or black tea, coffee, or milk with the meals. Alternatively, water or non-alcoholic beer.

times a week and drinking alcoholic beverages with/without meals daily or several times a week [106, 109]. Only few patients were offered dietary intervention. After consulting a dietician, some have shifted to a predominantly vegetarian diet and abstained from alcohol, which according to the persons' own statements clearly has decreased the rate of body iron accumulation as assessed by the time-related increase in serum ferritin (Milman NT, personal communication). The dietary interventions recommended in this paper are close to the official Danish dietary guidelines 2021 [92, 100]. The facts and the problems are, however, that only a minority of the Danish population adhere to the official dietary advices [100]. The presented dietary recommendations are by and large in accordance with those given by the Iron Disorders Institute [93].

Danish persons with hemochromatosis do not to any significant degree change their dietary habits once the diagnosis has been established [106, 109]. The reported dietary intervention studies have been implemented in the maintenance phase of the disease [9], as the effect is difficult to evaluate in the induction phase. However, the frequent phlebotomies in the induction phase are a strong stimulus for iron absorption [9, 10], which will tend to increase the number of blood-lettings, and therefore prolong the induction phase. In healthy persons, phlebotomy-induced anemia can increase the erythropoietic response by $200 \%$ above basal erythropoietic rate [110]. Persons with hemochromatosis have a normal erythropoiesis and regain their habitual hemoglobin level within a few weeks after phlebotomy. Consequently, it could be an advantage to introduce dietary measures early in the induction phase.

All persons/patients with hemochromatosis should be offered a consultation by a dietician and receive proper dietary advices. In this way patients can contribute actively to the management of their disease. However, it is up to the patients to decide to which extent they wish to follow the dietary recommendations and restructure their daily diet. In conclusion, until the results from prospective, controlled dietary studies are available, we will have to give persons with hemochromatosis dietary recommendations based on our present knowledge of body iron homeostasis, food iron content and intestinal iron uptake [10].

\section{Acknowledgments}

None to declare. 


\section{Financial Disclosure}

This study was supported by unrestricted grants from The Danish Haemochromatosis Association (Dansk Haemokromatose Forening, www.haemokromatose.dk) and Pharmovital ApS, Rosenkaeret 11B, DK-2860 Soeborg, Denmark.

\section{Conflict of Interest}

The author declares to have no conflict of interest.

\section{Informed Consent}

Not applicable.

\section{Author Contributions}

Nils T. Milman authored the entire manuscript.

\section{Data Availability}

This review is based on literature searches in the PubMed and Google Scholar databases as well as literature references cited in published articles, review papers and books on iron metabolism. The data used to support the recommendations and conclusions of this study are included in this article and in more details in a previous review paper [10].

\section{References}

1. Milman N, Pedersen P. Evidence that the Cys282Tyr mutation of the HFE gene originated from a population in Southern Scandinavia and spread with the Vikings. Clin Genet. 2003;64(1):36-47.

2. Milman NT, Schioedt FV, Junker AE, Magnussen K. Diagnosis and Treatment of Genetic HFE-Hemochromatosis: The Danish Aspect. Gastroenterology Res. 2019;12(5):221232.

3. Milman N, Koefoed P, Pedersen P, Nielsen FC, Eiberg H. Frequency of the HFE C282Y and H63D mutations in Danish patients with clinical haemochromatosis initially diagnosed by phenotypic methods. Eur J Haematol. 2003;71(6):403-407.

4. Pedersen P, Milman N. Genetic screening for HFE hemochromatosis in 6,020 Danish men: penetrance of C282Y, H63D, and S65C variants. Ann Hematol. 2009;88(8):775784.

5. Pilling LC, Tamosauskaite J, Jones G, Wood AR, Jones L, Kuo CL, Kuchel GA, et al. Common conditions associated with hereditary haemochromatosis genetic variants: cohort study in UK Biobank. BMJ. 2019;364:k5222.

6. Byrnes V, Ryan E, Barrett S, Kenny P, Mayne P, Crowe J. Genetic hemochromatosis, a Celtic disease: is it now time for population screening? Genet Test. 2001;5(2):127-130.

7. Lynch SR, Skikne BS, Cook JD. Food iron absorption in idiopathic hemochromatosis. Blood. 1989;74(6):21872193.

8. Walters GO, Jacobs A, Worwood M, Trevett D, Thomson W. Iron absorption in normal subjects and patients with idiopathic haemochromatosis: relationship with serum ferritin concentration. Gut. 1975;16(3):188-192.

9. Moretti D, van Doorn GM, Swinkels DW, Melse-Boonstra A. Relevance of dietary iron intake and bioavailability in the management of HFE hemochromatosis: a systematic review. Am J Clin Nutr. 2013;98(2):468-479.

10. Milman NT. A review of nutrients and compounds, which promote or inhibit intestinal iron absorption: making a platform for dietary measures that can reduce iron uptake in patients with genetic haemochromatosis. J Nutr Metab. 2020;2020:7373498.

11. Hunt JR, Zeng H. Iron absorption by heterozygous carriers of the HFE C282Y mutation associated with hemochromatosis. Am J Clin Nutr. 2004;80(4):924-931.

12. Ginzburg YZ. Hepcidin-ferroportin axis in health and disease. Vitam Horm. 2019;110:17-45.

13. Sharp PA. Intestinal iron absorption: regulation by dietary \& systemic factors. Int J Vitam Nutr Res. 2010;80(45):231-242.

14. Pietrangelo A. Hereditary hemochromatosis: pathogenesis, diagnosis, and treatment. Gastroenterology. 2010;139(2): 393-408, e391-392.

15. Conrad ME, Umbreit JN. Pathways of iron absorption. Blood Cells Mol Dis. 2002;29(3):336-355.

16. Green R, Charlton R, Seftel H, Bothwell T, Mayet F, Adams B, Finch C, et al. Body iron excretion in man: a collaborative study. Am J Med. 1968;45(3):336-353.

17. Hunt JR, Zito CA, Johnson LK. Body iron excretion by healthy men and women. Am J Clin Nutr. 2009;89(6):17921798.

18. Adams P, Altes A, Brissot P, Butzeck B, Cabantchik I, Cancado $\mathrm{R}$, Distante $\mathrm{S}$, et al. Therapeutic recommendations in HFE hemochromatosis for p.Cys282Tyr (C282Y/C282Y) homozygous genotype. Hepatol Int. 2018;12(2):83-86.

19. Tetens I, Bendtsen KM, Henriksen M, Ersboll AK, Milman N. The impact of a meat- versus a vegetable-based diet on iron status in women of childbearing age with small iron stores. Eur J Nutr. 2007;46(8):439-445.

20. Pawlak R, Berger J, Hines I. Iron Status of Vegetarian Adults: A Review of Literature. Am J Lifestyle Med. 2018;12(6):486-498.

21. Bach Kristensen M, Hels O, Morberg C, Marving J, Bugel $\mathrm{S}$, Tetens I. Pork meat increases iron absorption from a 5-day fully controlled diet when compared to a vegetarian diet with similar vitamin $\mathrm{C}$ and phytic acid content. Br J Nutr. 2005;94(1):78-83.

22. Hallberg L, Rossander-Hulten L. Iron requirements in menstruating women. Am J Clin Nutr. 1991;54(6):10471058.

23. Nordic Council of Ministers. Nordic nutrition recommendations 2012: Integrating nutrition and physical activity. Copenhagen, Denmark, 2019. http://dx.doi.org/10.6027/ Nord2014-002 Accessed January 30, 2021. 
24. Dietary Habits in Denmark 2011-2013, Main results, The National Food Institute, Danish Technical University, Kongens Lyngby, Denmark, 1st edition, February 2015. http://www.food.dtu.dk Accessed January 30, 2021.

25. Milman NT. Dietary Iron Intakes in Men in Europe Are Distinctly Above the Recommendations: A Review of 39 National Studies From 20 Countries in the Period 1995 2016. Gastroenterology Res. 2020;13(6):233-245.

26. Fagt S, Matthiessen J, Biltoft-Jensen A. Hvor meget kod spiser danskerne? - data fra statistikker og kostundersogelser (How much meat do the Danes consume? - data from statistics and nutrition surveys). E-artikel. Lyngby: Danmarks Tekniske Universitet, Foedevareinstituttet (Danish Technical University, Danish Veterinary and Food Administration). 2018.

27. Hytten FE, Cheyne GA, Klopper AI. Iron Loss at Menstruation. J Obstet Gynaecol Br Commonw. 1964;71:255-259.

28. Milman N. Iron and pregnancy - a delicate balance. Ann Hematol. 2006;85(9):559-565.

29. Milman NT. Dietary Iron Intake in Women of Reproductive Age in Europe: A Review of 49 Studies from 29 Countries in the Period 1993-2015. J Nutr Metab. 2019;2019:7631306.

30. Hurrell R, Egli I. Iron bioavailability and dietary reference values. Am J Clin Nutr. 2010;91(5):1461S-1467S.

31. Lonnerdal B, Bryant A, Liu X, Theil EC. Iron absorption from soybean ferritin in nonanemic women. Am J Clin Nutr. 2006;83(1):103-107.

32. Hoppler M, Schonbachler A, Meile L, Hurrell RF, Walczyk T. Ferritin-iron is released during boiling and in vitro gastric digestion. J Nutr. 2008;138(5):878-884.

33. West AR, Oates PS. Mechanisms of heme iron absorption: current questions and controversies. World J Gastroenterol. 2008;14(26):4101-4110.

34. U.S. Department of Agriculture. Food Data Central. https://ndb.nal.usda.gov/. Accessed January 30, 2021.

35. Foedevarestyrelsen, Danmarks Tekniske Universitet (National Food Institute, Technical University of Denmark). Food data. https://frida.fooddata.dk. Version 4, 2019. Accessed January 30, 2021.

36. Nederlands Voedingsstoffenbestand (NEVO). Bilthoven: Rijksinstituut voor Volksgezondheid en Miliey; 2016. https://nevo-online.rivm.nl/Default.aspx. Accessed January 30, 2021.

37. Skikne BS, Lynch SR, Cook JD. Role of gastric acid in food iron absorption. Gastroenterology. 1981;81(6):10681071.

38. Betesh AL, Santa Ana CA, Cole JA, Fordtran JS. Is achlorhydria a cause of iron deficiency anemia? Am J Clin Nutr. 2015;102(1):9-19.

39. European Food Safety Authority (EFSA). Scientific Opinion on the substantiation of health claims related to vitamin $\mathrm{C}$ and protection of DNA, proteins and lipids from oxidative damage (ID 129, 138, 143, 148), antioxidant function of lutein (ID 146), maintenance of vision (ID 141, 142), collagen formation (ID 130, 131, 136, 137, 149), function of the nervous system (ID 133), function of the immune system (ID 134), function of the immune system during and after extreme physical exercise (ID 144), non-haem iron absorption (ID 132, 147), energy-yielding metabolism (ID 135), and relief in case of irritation in the upper respiratory tract (ID 1714, 1715) pursuant to Article 13(1) of Regulation (EC) No 1924/2006. EFSA Panel on Dietetic Products, Nutrition and Allergies (NDA). European Food Safety Authority (EFSA), Parma, Italy. 2010.

40. European Food Safety Authority (EFSA). Scientific Opinion on the substantiation of a health claim related to vitamin $\mathrm{C}$ and increasing non-haem iron absorption pursuant to Article 14 of Regulation (EC) No 1924/20061. EFSA Panel on Dietetic Products, Nutrition and Allergies (NDA). Parma, Italy 2014.

41. Scheers N, Rossander-Hulthen L, Torsdottir I, Sandberg AS. Increased iron bioavailability from lactic-fermented vegetables is likely an effect of promoting the formation of ferric iron (Fe(3+)). Eur J Nutr. 2016;55(1):373-382.

42. Cook JD, Monsen ER. Food iron absorption in human subjects. III. Comparison of the effect of animal proteins on nonheme iron absorption. Am J Clin Nutr. 1976;29(8):859867.

43. Bjorn-Rasmussen E, Hallberg L, Isaksson B, Arvidsson B. Food iron absorption in man. Applications of the two-pool extrinsic tag method to measure heme and nonheme iron absorption from the whole diet. J Clin Invest. 1974;53(1):247-255.

44. Vela D. Low hepcidin in liver fibrosis and cirrhosis; a tale of progressive disorder and a case for a new biochemical marker. Mol Med. 2018;24(1):5.

45. Christides T, Sharp P. Sugars increase non-heme iron bioavailability in human epithelial intestinal and liver cells. PLoS One. 2013;8(12):e83031.

46. Pollack S, Kaufman RM, Crosby WH. Iron Absorption: Effects of Sugars and Reducing Agents. Blood. 1964;24:577-581.

47. O'Dell BL. Fructose and mineral metabolism. Am J Clin Nutr. 1993;58(5 Suppl):771S-778S.

48. Schlemmer U, Frolich W, Prieto RM, Grases F. Phytate in foods and significance for humans: food sources, intake, processing, bioavailability, protective role and analysis. Mol Nutr Food Res. 2009;53(Suppl 2):S330-375.

49. Siegenberg D, Baynes RD, Bothwell TH, Macfarlane BJ, Lamparelli RD, Car NG, MacPhail P, et al. Ascorbic acid prevents the dose-dependent inhibitory effects of polyphenols and phytates on nonheme-iron absorption. Am J Clin Nutr. 1991;53(2):537-541.

50. Yang J, Dwyer JT, Peterson JJ. Polyphenols in foods. What clinicians need to know. Nutrition Today. 2016;51(6):290300.

51. Lynch SR, Dassenko SA, Cook JD, Juillerat MA, Hurrell RF. Inhibitory effect of a soybean-protein-related moiety on iron absorption in humans. Am J Clin Nutr. 1994;60(4):567-572.

52. Hurrell RF, Lynch SR, Trinidad TP, Dassenko SA, Cook JD. Iron absorption in humans as influenced by bovine milk proteins. Am J Clin Nutr. 1989;49(3):546-552.

53. Callender ST, Marney SR, Jr., Warner GT. Eggs and iron absorption. Br J Haematol. 1970;19(6):657-665.

54. Hurrell RF, Lynch SR, Trinidad TP, Dassenko SA, Cook JD. Iron absorption in humans: bovine serum albumin 
compared with beef muscle and egg white. Am J Clin Nutr. 1988;47(1):102-107.

55. Lynch SR. The effect of calcium on iron absorption. Nutr Res Rev. 2000;13(2):141-158.

56. Hallberg L, Rossander-Hulthen L, Brune M, Gleerup A. Inhibition of haem-iron absorption in man by calcium. Br J Nutr. 1993;69(2):533-540.

57. Mitchell T, Kumar P, Reddy T, Wood KD, Knight J, Assimos DG, Holmes RP. Dietary oxalate and kidney stone formation. Am J Physiol Renal Physiol. 2019;316(3):F409F413.

58. genannt Bonsmann SS, Walczyk T, Renggli S, Hurrell RF. Oxalic acid does not influence nonhaem iron absorption in humans: a comparison of kale and spinach meals. Eur J Clin Nutr. 2008;62(3):336-341.

59. Menon VP, Sudheer AR. Antioxidant and anti-inflammatory properties of curcumin. Adv Exp Med Biol. 2007;595:105-125.

60. Benefits of turmeric for hemochromatosis. The BEST natural remedy shown by clinical research to reliably reduce the build-up of iron in the body. Turmeric can lower ferritin by chelating iron from the body. https://hemochromatosishelp.com/turmeric-benefit-for-hemochromatosis/. Accessed January 30, 2021.

61. Tuntipopipat S, Judprasong K, Zeder C, Wasantwisut E, Winichagoon P, Charoenkiatkul S, Hurrell R, et al. Chili, but not turmeric, inhibits iron absorption in young women from an iron-fortified composite meal. J Nutr. 2006;136(12):2970-2974.

62. Laine F, Laviolle B, Bardou-Jacquet E, Fatih N, Jezequel C, Collet N, Ropert M, et al. Curcuma decreases serum hepcidin levels in healthy volunteers: a placebo-controlled, randomized, double-blind, cross-over study. Fundam Clin Pharmacol. 2017;31(5):567-573.

63. Kulkarni R, Deshpande A, Saxena K, Varma M, Sinha ARS. Ginger supplementary therapy for iron absorption in iron deficiency anemia. Indian Journal of Traditional Knowledge. 2012;11(1):78-80.

64. Sharma DC, Chandiramani D, Riyat M, Sharma P. Scientific evaluation of some Ayurvedic preparations for correction of iron deficiency and anemia. Indian J Clin Biochem. 2007;22(2):123-128.

65. Alexander D, Ball MJ, Mann J. Nutrient intake and haematological status of vegetarians and age-sex matched omnivores. Eur J Clin Nutr. 1994;48(8):538-546.

66. Wilson AK, Ball MJ. Nutrient intake and iron status of Australian male vegetarians. Eur J Clin Nutr. 1999;53(3):189-194.

67. Mogensen L, Hermansen J, Nguyen L, Preda T. Environmental impact of beef by life cycle assessment (LCA) - 13 Danish beef production systems. Danish Center for Food and Agriculture. Report no.: 061. 2015, Aarhus Denmark.

68. SchweihoferJ. The color ofmeat depends on myoglobin: Part 1. Michigan State University Extension - October 10, 2014. https://www.canr.msu.edu/news/the color_of meat depends_on_myoglobin_part_1\#: :text=Myoglobin $\% 20$ stores $\overline{\%} 2 \overline{0}$ oxygen $\% 20 \mathrm{in} \% \overline{20}$ muscle, it $\% 20$ will $\% 20$ appear $\% 20$ in $\% 20$ color.\&text $=$ The $\% 20$ age $\% 20$ of $\% 20$ an $\% 20$ animal,more $\% 20$ myoglobin $\% 20$ and $\% 20$ darker $\% 20$ meat.
Accessed January 30, 2021.

69. Hurrell RF, Reddy MB, Juillerat M, Cook JD. Meat protein fractions enhance nonheme iron absorption in humans. J Nutr. 2006;136(11):2808-2812.

70. Baker-Austin C, Oliver JD. Vibrio vulnificus: new insights into a deadly opportunistic pathogen. Environ Microbiol. 2018;20(2):423-430.

71. Bullen JJ, Spalding PB, Ward CG, Gutteridge JM. Hemochromatosis, iron and septicemia caused by Vibrio vulnificus. Arch Intern Med. 1991;151(8):1606-1609.

72. Barton JC, Acton RT. Hemochromatosis and Vibrio vulnificus wound infections. J Clin Gastroenterol. 2009;43(9): 890-893.

73. Thilakarathna MS, Raizada MN. A meta-analysis of the effectiveness of diverse Rhizobia inoculants on soybean traits under field conditions. Soil Biology and Biochemistry. 2017;105:177-196.

74. Hanson LN, Engelman HM, Alekel DL, Schalinske KL, Kohut ML, Reddy MB. Effects of soy isoflavones and phytate on homocysteine, C-reactive protein, and iron status in postmenopausal women. Am J Clin Nutr. 2006;84(4):774780.

75. Reale A, Konietzny U, Coppola R, Sorrentino E, Greiner $\mathrm{R}$. The importance of lactic acid bacteria for phytate degradation during cereal dough fermentation. J Agric Food Chem. 2007;55(8):2993-2997.

76. Lopez HW, Krespine V, Guy C, Messager A, Demigne C, Remesy C. Prolonged fermentation of whole wheat sourdough reduces phytate level and increases soluble magnesium. J Agric Food Chem. 2001;49(5):2657-2662.

77. Milman N, Kirchhoff M. Relationship between serum ferritin, alcohol intake, and social status in 2235 Danish men and women. Ann Hematol. 1996;72(3):145-151.

78. Milman N, Byg KE, Ovesen L, Kirchhoff M, Jurgensen KS. Iron status in Danish men 1984-94: a cohort comparison of changes in iron stores and the prevalence of iron deficiency and iron overload. Eur J Haematol. 2002;68(6):332-340.

79. Milman N, Byg KE, Ovesen L, Kirchhoff M, Jurgensen KS. Iron status in Danish women, 1984-1994: a cohort comparison of changes in iron stores and the prevalence of iron deficiency and iron overload. Eur J Haematol. 2003;71(1):51-61.

80. Scotet V, Merour MC, Mercier AY, Chanu B, Le Faou T, Raguenes O, Le Gac G, et al. Hereditary hemochromatosis: effect of excessive alcohol consumption on disease expression in patients homozygous for the C282Y mutation. Am J Epidemiol. 2003;158(2):129-134.

81. Charlton RW, Jacobs P, Seftel H, Bothwell TH. Effect of Alcohol on Iron Absorption. Br Med J. 1964;2(5422):14271429.

82. Harrison-Findik DD. Is the iron regulatory hormone hepcidin a risk factor for alcoholic liver disease? World J Gastroenterol. 2009;15(10):1186-1193.

83. Cook JD, Reddy MB, Hurrell RF. The effect of red and white wines on nonheme-iron absorption in humans. Am J Clin Nutr. 1995;61(4):800-804.

84. Sundhedsstyrelsens udmeldinger om alkohol (Danish Health Authority, recommendations on alcohol intake). 
https://www.sst.dk/da/viden/alkohol/alkoholforebyggelse/ sundhedsstyrelsens-udmeldinger-om-alkohol. Accessed January 30, 2021.

85. Kaltwasser JP, Werner E, Schalk K, Hansen C, Gottschalk $\mathrm{R}$, Seidl C. Clinical trial on the effect of regular tea drinking on iron accumulation in genetic haemochromatosis. Gut. 1998;43(5):699-704.

86. Astill C, Birch MR, Dacombe C, Humphrey PG, Martin PT. Factors affecting the caffeine and polyphenol contents of black and green tea infusions. J Agric Food Chem. 2001;49(11):5340-5347.

87. National Institute of Diabetes and Digestive and Kidney Diseases. LiverTox: Clinical and research information on drug-induced liver injury. Green Tea. Bethesda (Maryland). Last updated November 20, 2020. https://www.ncbi. nlm.nih.gov/books/NBK547925/. Accessed January 30, 2021.

88. Kaffe, sundhed og sygdom (Coffee, health and disease). Hermansen K, Bech BH, Dragsted LO, Hyldstrup L, Jorgensen K, Larsen ML, Tjoenneland A. 2012. www.vidensraad.dk. Accessed January 30, 2021.

89. British Liver Trust. https://britishlivertrust.org.uk/wpcontent/uploads/The-health-benefits-of-coffee-BLT-report-June-2016.pdf. Accessed January 30, 2021.

90. Wijarnpreecha K, Thongprayoon C, Ungprasert P. Coffee consumption and risk of nonalcoholic fatty liver disease: a systematic review and meta-analysis. Eur J Gastroenterol Hepatol. 2017;29(2):e8-e12.

91. Brittin HC, Nossaman CE. Iron content of food cooked in iron utensils. J Am Diet Assoc. 1986;86(7):897-901.

92. Foedevarestyrelsen (Danish Veterinary and Food Administration). https://altomkost.dk/raad-og-anbefalinger/ de-officielle-kostraad-godt-for-sundhed-og-klima/. Accessed January 30, 2021.

93. Iron Disorders Institute. https://irondisorders.org/diet/. Accessed January 30, 2021.

94. van den Bergh JP, Bours SP, van Geel TA, Geusens PP. Optimal use of vitamin $\mathrm{D}$ when treating osteoporosis. Curr Osteoporos Rep. 2011;9(1):36-42.

95. U.S. National Institutes of Health. Office of Dietary Supplements. Vitamin E. Fact sheet for health professionals. July, 2020. https://ods.od.nih.gov/factsheets/VitaminEHealthProfessional/. Accessed January 30, 2021.

96. Sears B. Anti-inflammatory Diets. J Am Coll Nutr. 2015;34(Suppl 1):14-21.

97. Gigtforeningen (Danish Rheumatic Association). https:// www.gigtforeningen.dk/nyheder/2018/2-halvaar/faa- jerk-w-langers-bud-paa-antiinflammatorisk-livsstil/. Accessed January 30, 2021.

98. Calder PC. Omega-3 fatty acids and inflammatory processes. Nutrients. 2010;2(3):355-374.

99. Anderson EJ, Thayne KA, Harris M, Shaikh SR, Darden TM, Lark DS, Williams JM, et al. Do fish oil omega-3 fatty acids enhance antioxidant capacity and mitochondrial fatty acid oxidation in human atrial myocardium via PPARgamma activation? Antioxid Redox Signal. 2014;21(8):1156-1163.

100. Foedevarestyrelsen (Danish Veterinary and Food Administration). https://altomkost.dk/. Accessed January 30, 2021.

101. Det Etiske Rad (The Danish Council on Ethics). Sammenhaengen mellem kodspisning, klimaforandringer og fodevarekrise (The association between meat eating, climate changes and food crisis). 2011. https:/www. etiskraad.dk/etiske-temaer/natur-klima-og-foedevarer/undervisning-til-grundskolen/stamcellekoed/koedspisningog-klimaforandringer. Accessed January 30, 2021.

102. Knudsen L. Fakta om kvalstof i landbruget og vandmiljoet (Facts about nitrogen in the agriculture and the aquatic environment). SEGES, Agro Food Park, 1st edition. June 2017. Aarhus, Denmark.

103. Vegetarisk Forening (Vegetarian Association). https://vegetarisk.dk/statistik-om-danmark/. Accessed January 30, 2021.

104. Hesselberg J, Skjoet SH, Lahteenmaki L, Bech-Larsen T, Groenhoej A. Mindre koed i kosten? (Less meat in the diet?). Danish Center for Food and Agriculture. Report no.: 180. 2021, Aarhus Denmark.

105. Coop madpyramiden (Coop food pyramid). https://madpyramiden.dk. Accessed January 30, 2021.

106. Milman NT. Hvad blev der af diaetisten? (What became of the dietician?) Diaetisten. 2020;164:6-8.

107. Pedersen P, Milman N. Extrinsic factors modifying expressivity of the HFE variant C282Y, H63D, S65C phenotypes in 1,294 Danish men. Ann Hematol. 2009;88(10): 957-965.

108. Dansk Haemokromatose Forening (The Danish Haemochromatosis Association). https://www.haemokromatose. $\mathrm{dk} /$. Accessed January 30, 2021.

109. Milman NT. Stort behov for diaetetisk raadgivning til personer med arvelig haemokromatose (Great need for dietary counceling in persons with genetic haemochromatosis). Diaetisten. 2019;162:14-19.

110. Goodnough LT. Erythropoietin and iron-restricted erythropoiesis. Exp Hematol. 2007;35(4 Suppl 1):167-172. 